\title{
Controlling rainfall-induced soil loss from small experimental plots through inoculation of bacteria and cyanobacteria
}

\author{
Hossein Kheirfam $^{1}$, Seyed Hamidreza Sadeghi ${ }^{2 *}$, Behrouz Zarei Darki ${ }^{3}$ and Mehdi \\ Homaee $^{4}$ \\ ${ }^{1}$ Former PhD Student, Department of Watershed Management Engineering, Faculty of Natural Resources, Tarbiat \\ Modares University, Iran. E-Mail: H.Kheirfam@yahoo.com \\ ${ }^{2 *}$ Professor (Corresponding Author), Department of Watershed Management Engineering, Faculty of Natural \\ Resources, Tarbiat Modares University, Iran. E-Mail: Sadeghi@modares.ac.ir. \\ ${ }^{3}$ Assistant Professor, Department of Marine Biology, Faculty of Marine Science, Tarbiat Modares University, Iran. \\ E-Mail: Zarei@mail.ru \\ ${ }^{4}$ Professor, Department of Soil Science, Faculty of Agriculture, Tarbiat Modares University, Iran. E-Mail: \\ Mhomaee@modares.ac.ir
}

\begin{abstract}
Soil erosion is a major limitation for achieving sustainable development. Controlling soil detachment in initial stage of soil erosion induced by rainfall is necessary. Several organic and inorganic amendments have been used to reduce rainfall-induced erosion. Meanwhile, the impact of soil microorganisms has been approved on improving soil aggregation by previous studies. However, studying the feasibility of inoculation of soil microorganisms to reduce soil loss by rainfall-induced erosion has not been considered yet. Hence, the present study was planned to investigate the controllability of soil loss induced by rainfall-induced through the inoculation of bacteria and cyanobacteria into a study soil. Soil samples were collected from an erosion-prone area from which suitable existing bacteria and cyanobacteria for soil and water conservation were selected, purified and proliferated. The bacteria and cyanobacteria were then inoculated
\end{abstract}


into 24 small $0.25 \mathrm{~m}^{2}$ plots in individual and/or combined treatments at three time spans of 15 , 30 and 60 days. The results illustrated a significant decrease in soil loss from treated plots $(\mathrm{p}<0.01)$. Moreover, the highest effectiveness was observed in the cyanbacteria and the combined treatments at the end of the 60 days-period $(\mathrm{p}<0.01)$ with respective reduction rate of 99 and $98 \%$ in soil loss. Based on the study results, the use of microorganisms, particularly direct inoculation of bacteria and cyanobacteria can be supposed as a new step, biologic, sustainable, environmentally-friend and economically-effective technique for soil conservation.

Keywords: Soil Bio-amendment; Soil Conservation; Soil Erodibility; Soil Stabilizers; Soil Microorganisms Inoculation

\section{Introduction}

Soil is a key component of the earth system, as the soil system determines the cycles of the water, nutrients, minerals, life, and also provides the human well-being and ecosystem health (Brevik et al., 2015; Decock et al., 2015; Smith et al., 2015). Soil health plays a decisive role in achieving sustainable development (Keesstra et al., 2016; Kheirfam et al., 2017). Nevertheless, reducing the potential of soil affected by erosion particularly water erosion is serious universal challenge in achieving sustainable development (Biswas et al., 2015; Ochoa-Cueva et al., 2015; Gessesse et al., 2015; Martínez-Murillo et al., 2016; Vaezi et al., 2016). Hence, controlling and/or decreasing of soil erosion particularly in initial first steps of its appearance on hillslops initiated by rainfall erosion, could be an efficacious strategy to soil conservation. Therefore, various amendments have been implemented to reduce the adverse effects of rainfall-induced soil erosion. Accordingly, variety of amendments viz. gypsum, lime, sawdust and wood ash, municipal wastes (Sadeghi et al., 2016); organic composts, animal and crop manures, crop and food industries residues (Sadeghi et al., 2015); native plant residues mulching (Mwango et al., 
2015); secondary vegetation succession (van Hall et al., 2016); oil mulches and types of oil and biodegradable polymers (Zohuriaan-Mehr and Kabiri, 2008) were used to controlling soil erosion.

Despite some desirable applications of aforementioned amendments in reducing rainfall-induced soil erosion, introducing new, biological, affordable, permanent, environmental friendly and applicable techniques is inevitable. Accordingly, the bacteria and cyanobacteria which construct the biological soil crusts (BSCs) known ecosystem engineers (Chamizo et al., 2012) have been introduced as biological soil amendments. The BSCs microorganisms, particularly bacteria and cyanobacteria not only build soil micro-structures through exopolysaccharides secreting (EPSs), but also create soil macro-structures by connecting together and forming micro-networks (Colica et al., 2014). These conditions lead to amend the soil surface roughness (Reynolds et al., 2001), improving soil stability (Huang et al., 2002; Dougill and Thomas, 2004), increasing soil aggregation (Bashanand and de-Bashan, 2010), increasing porosity (Miralles et al., 2011) and water retention capacity (Chamizo et al., 2011), accumulating nutrients and increasing soil fertility (Rodríguez-Caballero et al., 2013; Kheirfam et al., 2017) and carbon sequestration (Bhattacharya et al., 2016; Kheirfam et al., 2017) as well.

Certainly, improving of above mentioned soil properties through microbial activity in soil surface may have direct and indirect effects on soil stability against erosion. In this regard, the role of rich BSCs in microorganisms has been approved in reducing soil erosion under rainfall simulation and scale plot and arid and semi-arid region conditions (Belnap et al., 2013; Rodriguez-Caballero et al., 2013; Zhao and Xu, 2013; Zhao et al., 2014; Wei et al., 2015; Chamizo et al., 2016). The effective role of enriched BSCs by inoculation of soil microorganism particularly bacteria and cyanobacteria have been reported in improving the desert soil stability 
(Colica et al., 2014), increasing soil resistance to wind erosion (Zaady et al., 2016), and improving quality of erodible soil (Kheirfam et al., 2017).

Reviewing of literatures showed that many studies have been conducted to assess the effectiveness of microorganisms to stabilize soil structure and improve soil quality in general. Accordingly, it has been hypothesized that increasing of cyanobacteria and bacteria population by direct inoculation on the soil would artificially improve the biological crust leading to improve soil physical, chemical and biological properties and as a consequence reduce soil loss from the small study plots with dominant rainfall-induced soil erosion. However, no document could be accessed to report the effect of inoculation of bacteria and cyanobacteria into soil in order to analyze their roles in reducing soil water erosion. The present study was therefore formulated to evaluate the role of direct and combined inoculation native bacteria and cyanobacteria to reduce soil loss by rainfall-induced erosion. In order to better control of the

study conditions, the study was planned under laboratorial physical simulation. Accordingly, small plots filled by an erosion-prone soil and a standard rainfall simulator were used for experimental processes.

\section{Material and Methods}

\subsection{Soil collection area and soil sampling}

The study soil was collected from a sub-watershed of Chalusrood Watershed (Kandelus Region) located in west of Mazandaran Province in Iran with an area of $86.34 \mathrm{~km}^{2}$. The study area has high susceptibility to erosion resulting in high sediment yield. The previous conservation measures such as exclosure, forestation and check dams had low level of success in controlling soil loss as well. The average annual precipitation and temperature based on the data collected from Kojour and Nowshahr stations (1978 to 2010) were $432 \mathrm{~mm}$ and $12{ }^{\circ} \mathrm{C}$, respectively. Based 
on USDA Soil Taxonomy classification method (USDA Soil Taxonomy, Soil Survey Staff, 2010), the soil was classified as fine loamy, mixed, mesic, typic calcixerepts, inceptisols. The soil texture was silty clay loam with 46,40 and $14 \%$ of silt, clay and sand contents, respectively. The bulk density of study soil was 1.10 to $1.20 \mathrm{~g} \mathrm{~cm}^{-3}$ with medium granular structure and fragile stability situation. The organic carbon content, humic acid, folic acid, lime percentage, $\mathrm{pH}$ and EC of the study soil were $\approx 0.18 \%, 0.017 \mathrm{~g} \mathrm{~kg}^{-1}, 0.03 \mathrm{~g} \mathrm{~kg}^{-1}, 27.9 \%, 7.42$ to 7.68 and 0.17 to 0.25 $\mathrm{ds} \mathrm{m}^{-1}$, respectively. The area has been mainly covered by Mediterranean Cypress forest (Cupressus sempervirens var. horizontalis) with less than $25 \%$ cover density.

Soil sampling was carried out by using $5 \mathrm{~cm}$-diameter coring polyvinyl chloride (PVC) from 2 $\mathrm{cm}$ of the surface layer (Chamizo et al., 2012) in September 2014. The collected soils were placed in polyethylene plastics bags, stored at approximately $4{ }^{\circ} \mathrm{C}$ (Kheirfam et al., 2017) and transported to the laboratory of the Natural Resource Faculty of Tarbiat Modares University. The soil samples were then air-dried and sieved by $2 \mathrm{~mm}$-sized mesh (Chamizo et al., 2012) and three composite samples were ultimately prepared by mixing $100 \mathrm{~g}$ of soil samples for further analyses.

\subsection{Preparation of culture media for bacteria and cyanobacteria isolation}

In the present study, the general media were used in order to extract the various genera of bacteria and cyanobacteria in soil microorganisms' bank. Thus, a wide number of soil bacteria and cyanobacteria general media were investigated and evaluated. Finally, Chu10 and Bold's basal general media (Andersen, 2005) were selected for cyanobacteria isolation. In addition, Nutrient Agar and Tryptic Soy Agar (TSA) (Eevers et al., 2015) general media were selected for bacteria isolation. The soil bacteria were cultured and isolated according to standard protocols 
described by Benson (2002). Accordingly, $1 \mathrm{~g}$ of soil samples in three replications were mixed with $0.85 \% \mathrm{NaCl}$ solution (physiological saline) in 1:10 ratio into Erlenmeyer flasks $\left(10^{-1}\right.$ dilution) for extraction of soil bacteria. Next, $1 \mathrm{ml}$ of prepared solution was transferred into a glass bottle $\left(10^{-2}\right)$ which it was further diluted up to $10^{-10}$. Each bottle contained $9 \mathrm{ml}$ saline solution. Afterwards, $1 \mathrm{ml}$ solution from each of the dilutions was placed in the corresponding individual $8 \mathrm{~cm}$ diameter Petri-dishes for each general bacteria media and with two replications in order to increase reliability. Afterwards, number of bacteria in $1 \mathrm{~g}$ soil was calculated by manually colony counting and optical density factor (Awad et al., 2011).

In order to identify the bacteria, colonies of bacteria were isolated from the surface of Petri dishes by using microbiological loop. The Gram staining was then carried out followed by microscopic examination as well as morphological characteristics (Bergey and Breed, 1957).

In order to isolate and identify the cyanobacteria, $1 \mathrm{~g}$ of soil samples were transferred into $8 \mathrm{~cm}$ diameter Petri-dishes with three replications. Then, $5 \mathrm{ml}$ Bold's basal and Chu10 media were also poured into Petri-dishes, separately. The cover glasses were then placed inside of Petridishes. The cyanobacteria were ultimately identified by using high-resolution optical microscopes based on morphological characterization at genus level (Whitton and Potts; 2012), since genus level of microorganisms identification was just needed for the present purposes. Though, molecular identification technique could also be applied for further detailed identification of microorganisms and at species level.

\subsection{Selection and purification of appropriate bacteria and cyanobacteria}

Various characteristics of isolated bacteria and cyanobacteria viz. power viability, activity in different soil temperatures, $\mathrm{pH}$ and moisture conditions, secretion of adhesive polysaccharides and network growth suggested by former scientists (e.g., Castenholz, 2001; Moore et al., 2006; 
Fierer et al., 2007; Kumar et al., 2007; Méjean et al., 2009; Satapute et al., 2012) were scrutinized for selection of appropriate bacteria and cyanobacteria targeting soil conservation purposes. Creation of small and large structures, converting food into usable forms for the other organisms, easy isolation and proliferation under laboratory conditions and also non-pathogenic effect on humans and other organisms were also considered. The most appropriate bacteria and cyanobacteria were ultimately selected for soil and water conservation targets. Accordingly, Azotobacter Agar, Modified II (Atlas, 2010) and DSMZ1 (Schrey et al., 2012) selective media were used in order to purify the selected bacteria. In addition, the colonies of selected cyanobacteria grown on the surface of coverglasses were picked by microbiological loop and transferred into a $20 \mathrm{ml}$ of sterile Bold's basal and Chu10 media in 50 ml-falcon tubes. This process was repeatedly continued during several steps until complete purification. The purified bacteria and cyanobacteria were then transferred by microbiological loops into liquid Luria Broth (LB) medium series of 50, 100, 500, 1000 and 2000ml, respectively (Garbeva et al., 2011) to achieve the suitable density of $10^{12} \mathrm{CFU}^{-1}$.

\subsection{Preparation of experimental plots}

A total 36 series of $0.25 \mathrm{~m}^{2}$-erosion plots with the depth of $0.5 \mathrm{~m}$ were used to conduct the study. Due to small size of the plots, the rainfall-induced soil erosion was governed the experimental conditions during which soil detachment mainly occurred owing to raindrops effects and the detached sediments were transported by a very film laminar flow (Kinnell, 2016). The experimental plots slope was set as $25 \%$ and similar to the most frequent slope of the soil origin. The experimental soil was transferred from the study area to the Rainfall and Erosion Simulation Laboratory of Faculty of Natural Resources of Tarbiat Modares University, Noor City, Iran. The collected soil was prepared by the procedure proposed by Sadeghi et al. (2015). 
Accordingly, soils were homogenized and passed through 8 and $3 \mathrm{~mm}$ sieves to use for the 2-30 $\mathrm{cm}$ and 0-2 cm layers, respectively. Soil permeability, bulk density, layer thickness and particle size distribution of the field soil was replicated as closely as possible, using methodologies suggested by Sadeghi et al. (2016). To facilitate drainage and to most closely mimic the field setting, the bottoms of the boxes were made of perforated sheet metal, covered by three layers of mineral pumice grains of different sizes a total thickness of $30 \mathrm{~cm}$. The soil was then compacted with a concrete roller to achieve the bulk density of $1.15 \mathrm{~g} \mathrm{~cm}^{-3}$, equal to that measured at the field site.

Using a randomized block design, we had three replicates of the following treatments: (i) individual inoculation of bacteria and cyanobacteria, (ii) combined inoculation of bacteria and cyanobacteria in order to investigate the synergic effects of symbiosis (Wang et al., 2009; Zaady

et al., 2016) and (iii) control i.e., without inoculation. Three time spans of 15, 30 and 60 days from the time of inoculating were set to assess the effect of time on microorganisms' performance. In addition, almost $10^{12} \mathrm{CFU}$ in $500 \mathrm{ml}$ (Valencia et al., 2014; Kheirfam et al., 2017) of proliferated bacteria and cyanobacteria were considered to inoculate to the surface soil of the plots through spraying technique (Wang et al., 2009; Kheirfam et al., 2017). The processes of bacteria and cyanobacteria inoculating on plots have been shown in Figure 1.

\subsection{Rainfall simulation}

A portable rainfall simulator with a height of about 4m and BEX: 3/8 S24W pressure nozzles was applied for the study, creating an average terminal velocity of about $7 \mathrm{~m} \mathrm{~s}^{-1}$ (Sadeghi et al, 2016) uniformly distributed on the entire area of the study plots (Sadeghi et al., 2013). The rainfall intensity of $50 \pm 2 \mathrm{~mm} \mathrm{~h}^{-1}$ with duration of 100 min was considered corresponding to 
climatological conditions giving the soil origin area and analysis made for the data collected from the nearest Kojour and Nowshahr weather stations with a return period of some 30 years (Sadeghi et al., 2015). The rainfall simulator was suitably adapted for simulation of particle size and distribution of rainfall in northern part of Iran (Sadeghi et al., 2013, 2016). After rainfall simulation the amount of soil loss was then measured according to Sadeghi et al. (2015) description. Accordingly, the collection gutter at the lower end of each plot was protected by a shield to prevent directly entrance of rainfall into the collection container. The amount of soil loss was then measured using the decantation procedure; oven-drying at $105{ }^{\circ} \mathrm{C}$ for $24 \mathrm{~h}$ and weighing by means of high precision scale. The entire procedures have been depicted in Figure 1.

Figure 1

\subsection{Statistical analyses}

All the measurements of samples were performed in triplicate. The normality and homogeneity of variances of the data were verified using the Shapiroe-Wilk and the Levine's tests, respectively. The one-way analysis of variance (ANOVA) was performed to test the global effect of treatments on induced rainfall-induced soil loss at each sampling time. If the global effect was significant $(\mathrm{P}<0.05)$, a Tukey HSD test was then performed to test the level of significance $(\alpha=0.05)$ between the control and each treatment.

\section{Results and Discussion}

\subsection{Appropriate bacteria and cyanobacteria}


The results showed that the number of bacteria and cyanobacteria in the study soil were $7.6 \times 10^{4}$ and $2.6 \times 10^{3} \mathrm{CFU} \mathrm{\textrm {g } ^ { - 1 }}$, respectively. While, the numbers of bacteria and cyanobacteria have been reported approximately $10^{5}$ to $10^{9} \mathrm{CFU} \mathrm{g}^{-1}$ in different soils (Gans et al., 2005). It clearly indicated that the soil microorganisms' bank of the study area was poor. The identification results also showed that six species of bacteria viz. Pseudomonas, Arthrobacter, Azotobacter, Diplococcus, Streptococcus and Bacillus existed in the study soil with population number of $2.65 \times 10^{4}, 1.49 \times 10^{4}, 7.6 \times 10^{3}, 1.9 \times 10^{4}, 3.8 \times 10^{3}$ and $2.54 \times 10^{3} \mathrm{CFU} \mathrm{g}^{-1}$, respectively. Besides those, five species of cyanobacteria viz. Nostoc and Oscillatoria with respective population number of $1.8 \times 10^{3}$ and $5.2 \times 10^{2} \mathrm{CFU} \mathrm{g}^{-1}$ as well as Lyngbya, Phormidium, Aphanothece with total population number of $2.6 \times 10^{2} \mathrm{CFU} \mathrm{g}^{-1}$ were recognized in the study soil. The characteristics of identified bacteria and cyanobacteria have been summarized in Supplementary Tables 1 and 2. Based on desired characteristics explained before, the Azotobacter and Bacillus subtilis strain from bacteria and also Nostoc, Oscillatoria and Lyngbya from cyanobacteria were selected as the most appropriate microorganisms to be applied for targeting the study goals. In this regard, Huixia et al. (2007) introduced Oligotrophic bacteria including Bacillus as suitable bacteria for soil characteristics improvement in deserts. Maqubela et al. (2009) reported that the soil aggregate and carbon sequestration increased after Nostoc inoculation on corn field soil. Nisha et al. (2007) showed a decrease in bulk density and increase in water holding capacity and hydraulic conductivity after cyanobacteria inoculation on pots filled by semi-arid land soil. The result of proliferation of bacteria and cyanobacteria indicated that the population of Azotobacter and Bacillus subtilis strain increased from $1.3 \times 10^{4}$ and $6.4 \times 10^{4}$ to $6.25 \times 10^{14}$ and $2 \times 10^{15} \mathrm{CFU}^{-1}$, respectively, at the end of eighth day. The population of Nostoc and combination of Oscillatoria 
and Lyngbya also increased from $4.7 \times 10^{3}$ and $0.9 \times 10^{3}$ to $1.5 \times 10^{14}$ and $3.9 \times 10^{13} \mathrm{CFU}^{-1}$, respectively, at the end of $21^{\text {st }}$ day.

\subsection{Effect of bacteria and cyanobacteria inoculation on soil loss}

The entire study plots were subjected to the study treatments as already explained whose corresponding results have been summarized in Table1 and supplementary Tables 3; and Figures 2 and 3 as well. The results showed that after rainfall simulation process, the amount soil loss in control plots were $10.53,9.36$ and $11.85 \mathrm{~g}$ in time spans of 15,30 and 60 days, respectively, against those reported for plots inoculated by bacteria as $1.13,0.37$ and $0.73 \mathrm{~g}$. So that, the amount of soil loss in inoculated bacteria treatments decreased significantly $(\mathrm{p}<0.01)$ about 89 , 96 and $93 \%$ at respective time spans.

Table 1

Figure 2

Figure 3

The effect of bacteria inoculation on soil loss reduction can be inferred to the secreted exopolysaccharides and produced bio-films by bacteria (Huang et al., 2002) which connected the soil fine particles to each other. Consequently, constructed the larger particles easily withstand against soil erosion. Additionally, the bacteria adhered around the very fine soil particles through their sticky, resistant, protein and hydrophobic multilayered cell walls (Tripathi et al., 2012) leading to larger and more resistant particles. Therefore, the soil particles were connected strongly together by adequate number of bacteria and made stable soil aggregates which resisted 
against rainfall shear stress (Carrasco et al., 2009). Therefore, thresholds of detachment and the motion of particles would be increase. Huang et al. (2015) reported that the fine clay particles were connected through bio-films produced by Bacillus subtilis bacteria. Carrasco et al. (2009) also found that the soil aggregate stability increased about $45 \%$ after inoculation of Bacillus cereus bacteria.

A significant reduction $(\mathrm{p}<0.01)$ in soil loss was observed in plots treated by cyanobacteria inoculation. So that, the amount of soil loss in cyanobacteria inoculated treatments at 15,30 and 60 days-time spans were about $2.08,0.73$ and $0.12 \mathrm{~g}$ with respective reduction of 73,92 and $98 \%$ compared to those obtained for the control condition. The effects of cyanobacteria treatments for short span of 15 days were not high, since the cyanobacteria network structures were not formed completely due to the low speed of cyanobacteria expansion and the soil particles connections were therefore remained weak (Kheirfam et al., 2017). While, the formation of the cyanobacteria networks in other time spans got completed (Bashanand and de-Bashan, 2010) and the soil particles connection became stronger and had more resistance against rainfall-induced detachment and surface runoff transport. In agreement with these findings, Issa et al. (2007) showed that the Nostoc sp. cyanobacteria inoculation increased the soil aggregate stability about $14 \%$.

The combined inoculation of bacteria and cyanobacteria indicated that amount of soil loss at 15 days-time span was $0.84 \mathrm{~g}$, and at the 30 and 60 days-time spans were about $0.20 \mathrm{~g}$. It clearly showed that the synergic effect of combination of bacteria and cyanobacteria could significantly $(p<0.01)$ reduce soil loss with respective rates of 92,97 and $98 \%$. The results also showed that in short time span of 15 days, the combined inoculation of bacteria and cyanobacteria could reduce the soil loss. Because, the population of bacteria and cyanobacteria increased rapidly after 
inoculation and in turn, a large volume of microbial exopolysaccharides (EPSs) were extensively produced. The EPSs then tackled the effects of raindrop splash through water absorption and creation a protective layer around soil particles (Chamizo, 2014). Besides those, the proliferation rate of bacteria was higher than the cyanobacteria. Therefore, they could increase runoff infiltration, create protective layer and connect very fine soil particles through adhering around the soil fine particles. The network filaments of cyanobacteria could further extend at longer time spans of 30 and 60 days and could supplement a protective role caused by bacteria and also EPSs effects. Therefore, the soil loss considerably decreased due to the decrease of volume and breakdown power of runoff. The decrease of runoff may occur due to increase of soil aggregate stability, porosity and infiltration (Wei et al., 2015). A microscopic view of inoculated cyanobacteria and their role on soil structure has been illustrated in Figure 3.

Since the runoff was not formed in small plots (Sadeghi et al., 2015), the study treatments decreased soil loss through splash erosion control. In this regard, Dougill and Thomas (2004) and Rodriguez-Caballero et al. (2013) proved rapid reform of crusts and the effect of biological soil crusts dominated cyanobacteria on soil loss reduction at plot scale. Zhao and Xu (2013) reported a reduction rate of $92 \%$ in sediment concentration in hillslope areas dominated by cyanobacteria. Belnap et al. (2013) observed that the soil loss in rich BSCs dominated by cyanobacteria decreased 400\% compared to poor BSCs. Zhao et al. (2014) findings also showed that the BSCs highly dominated by soil microorganisms were resistant against the kinetic energy of raindrops to 15 times higher than BSCs little dominated by soil microorganisms. Although, RodriguezCaballero et al. (2013) confirmed the positive effect of the lichen BSCs on soil hydrophobicity and thus, indirectly retarded water infiltration and increased runoff as well as soil loss. Nonetheless, inoculation of cyanobacteria on widespread area has been reported successfully to 
aim of improving the soil physical and chemical properties (Wang et al., 2009; Colica et al., 2014).

\section{Conclusions}

Our experiment showed that artificial increasing of soil microorganisms' population by direct inoculation technique can effectively increase soil stability against rainfall-induced soil erosion. However, analysis of direct and indirect roles of microorganisms' inoculation on soil behavior is essential for understanding the soil loss controlling process. We found that simultaneous inoculation of autotrophic (cyanbacteria) and heterotrophic (bacteria) microorganisms on soil surface can be decreased rainfall-induced soil erosion at short and long-term. By and large, the application of bacteria and cyanobacteria inoculation on soil can be supposed as an economically-effective and environmentally friend strategy and practically accessible bio-tool in the near future to soil conservationists. Though, more insight studies on applicability of soil microorganisms on larger plots and/or small natural micro-watersheds will be required to test the approach effectiveness against runoff induced soil loss.

\section{Acknowledgements}

The authors would like to dedicate their thanks to Tarbiat Modares University for providing appropriate facilities at Rainfall Simulation and Soil Erosion Laboratory of Faculty of Natural Resources Noor, Iran, where all lab works have been conducted. Later, this research has been partly supported by the Iran National Science Foundation (Project No. 94009347) whose valuable assistance is greatly appreciated. The authors would also thank Dr. Mehdi Vafakhah due to his cooperation in hydrologic aspects of the research. 


\section{References}

Andersen R.A., 2005. Algal culturing techniques, Elsevier Academic Press, London. 578p.

Atlas R.M., 2010. Handbook of microbiological media, $\left(4^{\text {th }}\right.$ ed.). Taylor and Francis Group publication, LLC. 2036p.

Awad, Y.M., Blagodatskaya, E., Ok, Y.S., Kuzyakov, Y., 2012. Effects of polyacrylamide, biopolymer, and biochar on decomposition of soil organic matter and plant residues as determined by 14C and enzyme activities. Eur. J. Soil Biol. 48, 1-10.

Bashan, Y., de-Bashan, L.E., 2010. Microbial populations of arid lands and their potential for restoration of deserts. In Soil biology and agriculture in the tropics. Springer Berlin Heidelberg 109-137.

Belnap, J., Wilcox, B.P., Van Scoyoc, M.W., Phillips, S.L., 2013. Successional stage of biological soil crusts: an accurate indicator of ecohydrological condition. Ecohydrology 6(3), 474-482.

Benson, H.J., 2002. Microbiological applications: laboratory manual in general microbiology, (8th ed.), short version, McGraw Hill, Boston, MA, USA. 384p.

Bergey, D.H., Breed, R.S., 1957. Bergey's manual of determinative bacteriology. (7 $7^{\text {th }}$ ed.). American Society for Microbiology. Baltimore, Williams and Wilkins Co. 1134p.

Biswas H., Raizada A., Mandal D., Kumar S., Srinivas S., Mishra P.K., 2015. Identification of areas vulnerable to soil erosion risk in India using GIS methods. Solid Earth 6(4), 12471257.

Brevik, E. C., Cerdà, A., Mataix-Solera, J., Pereg, L., Quinton, J. N., Six, J., Van Oost, K., 2015. The interdisciplinary nature of soil, Soil 1, 117-129. 
Carrasco, L., Caravaca, F., Azcón, R., Roldán, A., 2009. Soil acidity determines the effectiveness of an organic amendment and a native bacterium for increasing soil stabilisation in semiarid mine tailings. Chemosphere 74(2), 239-244.

Castenholz, R.W., 2001. General characteristics of the cyanobacteria. Bergey's Manual of Systematics of Archaea and Bacteria, 1-23

Chamizo S., 2014. The role of physical and biological soil crusts on the water balance in semiarid ecosystems. Universidad Almeria, 235p.

Chamizo, S., Cantón, Y., Domingo, F., Belnap, J., 2011. Evaporative losses from soils covered by physical and different types of biological soil crusts. Hydrol. Process. 27(3), 324-332.

Chamizo, S., Cantón, Y., Miralles, I., Domingo, F., 2012. Biological soil crust development affects physicochemical characteristics of soil surface in semiarid ecosystems. Soil Biol. Biochem. 49, 96-105.

Chamizo, S., Rodríguez-Caballero, E., Román, J.R., Cantón, Y., 2016. Effects of biocrust on soil erosion and organic carbon losses under natural rainfall. Catena (In press). doi:10.1016/j.catena.2016.06.017

Colica, G., Li, H., Rossi, F., Li, D., Liu, Y., De Philippis, R., 2014. Microbial secreted exopolysaccharides affect the hydrological behavior of induced biological soil crusts in desert sandy soils, Soil Biol. Biochem. 68, 62-70.

Decock, C., Lee, J., Necpalova, Pereira, M.E.I.P., Tendall, D.M., Six, J., 2015. Mitigating $\mathrm{N}_{2} \mathrm{O}$ emissions from soil: from patching leaks to transformative action. Soil 1, 687-694.

Deng, J, Ornerm E.P., Chau J.F., Anderson, E.M., Kadilak, A.L., Rubinstein, R.L., Bouchillon, G.M., Goodwin, R.A., Gage, D.J., Shor, L.M., 2015. Synergistic effects of soil 
microstructure and bacterial EPS on drying rate in emulated soil micromodels. Soil Biol. Biochem. 83, 116-124.

Eevers, N., Gielen, M., Sánchez-López, A., Jaspers, S., White, J.C., Vangronsveld, J., Weyens, N., 2015. Optimization of isolation and cultivation of bacterial endophytes through addition of plant extract to nutrient media. Microb. Biotechnol. 8(4), 707-715.

Fierer, N., Bradford, M.A., Jackson, R.B., 2007. Toward an ecological classification of soil bacteria. Ecology 88(6), 1354-1364.

Gans, J., Woilinsky, M., Dunbar, J., 2005. Computational improvements reveal great bacterial diversity and high metal toxicity in soil. Science 309, 1387-1390.

Garbeva, P., Tyc, O., Remus-Emsermann, M.N.P., Van der Wal, A., Vos, M., Silby, M., de Boer, W., 2011. No apparent costs for facultative antibiotic production by the soil bacterium Pseudomonas fluorescens Pf0-1. PLoS One 6(11), e27266.

Gessesse B., Bewket W., Bräuning A., 2015. Model-based characterization and monitoring of runoff and soil erosion in response to land use/land cover changes in the Modjo Watershed, Ethiopia. Land Degrad. Dev. 26(7), 711-724.

Huang, P.M., Bollag, J.M., Senesi, N., 2002. Interactions between soil particles and microorganisms: impact on the terrestrial ecosystem. John Wiley \& Sons, 566p.

Huang, Q., Wu, H., Cai, P., Fein, J.B,, Chen, W., 2015. Atomic force microscopy measurements of bacterial adhesion and biofilm formation onto clay-sized particles. Sci. Rep. 5, 16857.

Huixia, P., Zhengming, Ch., Xuemei, Zh., Shuyong, M., Xiaoling, Q., Fang, W., 2007. A study on an oligotrophic bacteria and its ecological characteristics in an arid desert area. CI China. Ser. D. 50, 128-134. 
Issa, O.M., Défarge, C., Le Bissonnais Y, Marin, B., Duval, O., Bruand, A., Luigi D’Acqui, P., Nordenberg, S., Annerman, M., 2007. Effects of the inoculation of cyanobacteria on the microstructure and the structural stability of a tropical soil. Plant Soil 290(1-2), 209-219.

Keesstra, S.D., Bouma, J., Wallinga, J., Tittonell, P., Smith, P., Cerdà, A., Montanarella, L., Quinton, J.N., Pachepsky, Y., van der Putten, W.H., Bardgett, R.D., Moolenaar, S., Mol, G., Jansen, B., Fresco, L.O., 2016. The significance of soils and soil science towards realization of the United Nations Sustainable Development Goals, Soil 2, 111-128.

Kheirfam, H., Sadeghi, S.H.R., Homaee, M., Zarei Darki, B., 2017. Quality improvement of an erosion-prone soil through microbial enrichment. Soil Tillage Res. 165, 230-238.

Kinnell, P.I.A., 2016. A review of the design and operation of runoff and soil loss plots. Catena $145,257-265$.

Kumar, R., Bhatia R., Kukreja, K., Behl, R.K., Dudeja, S.S., Narula, N. 2007. Establishment of Azotobacter on plant roots: chemotactic response, development and analysis of root exudates of cotton (Gossypium hirsutum L.) and wheat (Triticum aestivum L.). J. Basic Microbiol. 47(5), 436-439.

Maqubela, M.P., Mnkeni, P.N.S., Issa, O.M., Fernández, P., Teresa, M., D’Acqui, L.P., 2009. Nostoc cyanobacterial inoculation in South African agricultural soils enhances soil structure, fertility, and maize growth. Plant Soil 315, 79-92.

Martínez-Murillo, J.F., Nadal-Romero, E., Regües, D., Cerdà, A., Poesen, J., 2013. Soil erosion and hydrology of the western Mediterranean badlands throughout rainfall simulation experiments: A review. Catena 106, 101-112.

Méjean, A., Mann, S., Maldiney, T., Vassiliadis, G., Lequin, O., Ploux. O., 2009. Evidence that biosynthesis of the neurotoxic alkaloids anatoxin-aand homoanatoxin-a in the 
cyanobacterium Oscillatoria PCC 6506 occurs on a modular polyketide synthase initiated by L-proline. J. Am. Chem. Soc. 131, 7512-7513.

Miralles, I., Cantón, Y., Solé-Benet, A., 2011. Two-dimensional porosity of crusted silty soils: indicators of soil quality in semiarid rangelands? Soil Sci. Am. J. 75, 1289-1301.

Moore, E.R.B., Tindall, B.J., Martins Dos Santos, V.A.P., Pieper, D.H., Ramos, J.L., Palleroni, N. J., 2006. Nonmedical: Pseudomonas. Chapter 3.3.21. Prokaryotes 6, 646-703.

Mwango, S.B., Msanya, B.M., Mtakwa, P.W., Kimaro, D.N., Deckers, J., Poesen, J., 2015. Effectiveness of mulching under miraba in controlling soil erosion, fertility restoration and crop yield in the usambara mountains, Tanzania. Land Degrad. Dev. 27(4), 12661275.

Nisha, R., Kaushik, A., Kaushik, C.P., 2007. Effect of indigenous cyanobacterial application on structural stability and productivity of an organically poor semi-arid soil. Geoderma 138(1), 49-56.

Ochoa-Cueva P., Fries A., Montesinos P., Rodríguez-Díaz J.A., Boll J., 2015. Spatial estimation of soil erosion risk by land-cover change in the Andes of southern Ecuador. Land Degrad. Dev. 26 (6), 565-573.

Reynolds, R., Belnap, J., Reheis, M., Lamothe, P., Luiszer, F., 2001. Aeolian dust in Colorado Plateau soils: nutrient inputs and recent change in source. Proceedings of the National Academy of Sciences of the United States of America 98, 7123-7127.

Rodríguez-Caballero, E., Cantón, Y., Chamizo, S., Lázaro, R., Escudero, A., 2013. Soil loss and runoff in semiarid ecosystems: A complex interaction between biological soil crusts, micro-topography, and hydrological drivers. Ecosystems 16(4), 529-546. 
Rossi, F., Olguin, E.J., Diels, L., De Philippis, R., 2015. Microbial fixation of $\mathrm{CO}_{2}$ in water bodies and in drylands to combat climate change, soil loss and desertification. New Biotechnol. 32(1), 109-120.

Sadeghi, S.H.R., Abdollahi, Z., Khaledi Darvishan, A.V., 2013. Experimental comparison of some techniques for estimating natural rain drop size distribution in Caspian Sea southern coast, Iran. Hydrol. Sci. J. 58, 1374-1382.

Sadeghi, S.H.R., Gholami, L., Sharifi, E., Khaledi Darvishan, A.V., Homaee, M., 2015. Scale effect on runoff and soil loss control using rice straw mulch under laboratory conditions. Solid Earth 6, 1-8.

Sadeghi, S.H.R., Hazbavi, Z., Kiani Harcheganim M. 2016. Controllability of runoff and soil loss from small plots treated by vinasse-produced biochar. Sci. Total Environ. 541, 483490.

Satapute, P. P., Olekar, H. S., Shetti, A. A., Kulkarni, A. G., Hiremath, G. B., Patagundi, B. I., Shivsharan, C. T., Kaliwal, B. 2012. Isolation and characterization of nitrogen fixing bacillus subtilis strain as-4 from agricultural soil. Int. J. Recent Sci. Res. 3(9), 762-765.

Schrey, S.D., Erkenbrack, E., Früh, E., Fengler, S., Hommel, K., Horlacher, N., Schulz,D., Ecke, M., Kulik, A., Fiedler, H.P., Hampp, R., Tarkka, M.T., 2012. Production of fungal and bacterial growth modulating secondary metabolites is widespread among mycorrhizaassociated streptomycetes. BMC Microbiol. 12, 164.

Smith, P., Cotrufo, M.F., Rumpel, C., Paustian, K., Kuikman, P.J., Elliott, J.A., McDowell, R., Griffiths, R.I., Asakawa, S., Bustamante, M., House, J.I., Sobocká, J., Harper, R., Pan, G., West, P.C., Gerber, J.S., Clark, J.M., Adhya, T., Scholes, R.J., Scholes, M.C., 2015. 
Biogeochemical cycles and biodiversity as key drivers of ecosystem services provided by soils. Soil 1, 665-685.

Soil Survey Staff, 2010. Keys to Soil Taxonomy, $11^{\text {th }}$ ed. USDA-Natural Resources Conservation Services, Washington, DC.

Tripathi, P., Beaussart, A., Andre, G., Rolain, T., Lebeer, S., Vanderleyden, J., Hols, P., Dufrêne, Y.F., 2012. Towards a nanoscale view of lactic acid bacteria. Micron 43(12), 1323-1330.

Vaezi, A.R., Hasanzadeh, H., Cerdà, A., 2016. Developing an erodibility triangle for soil textures in semi-arid regions, NW Iran. Catena 142, 221-232.

Valencia, Y., Camapum, J., Torres, F.A., 2014. Influence of biomineralization on the physicomechanical profile of a tropical soil affected by erosive processes. Soil Biol. Biochem. 74, 98-99.

van Hall, R.L., Cammeraat, L.H., Keesstra, S.D. and Zorn, M., 2016. Impact of secondary vegetation succession on soil quality in a humid Mediterranean landscape. Catena (In Press). http://dx.doi.org/10.1016/j.catena.2016.05.021

Wang, W.B., Liu, Y.D., Li, D.H., Hua, C.X., Rao, B.Q., 2009. Feasibility of cyanobacterial inoculation for biological soil crusts formation in desert area. Soil Biol. Biochem. 41, 926-929.

Wei, W, Yum Y, Chen, L.m 2015. Response of surface soil hydrology to the micro-pattern of bio-crust in a dry-land Loess environment, China. PLoS One 10(7), e0133565.

Whitton B.A., Potts M., 2012. Introduction to the cyanobacteria. In Ecology of Cyanobacteria II, Springer Netherlands, 1-13. 
Zhao, Y., Qin, N., Weber, B., Xu, M., 2014. Response of biological soil crusts to raindrop erosivity and underlying influences in the hilly Loess Plateau region, China. Biodivers. Conserv. 23(7), 1669-1686.

Zhao, Y., Xu, M., 2013. Runoff and soil loss from revegetated grasslands in the hilly Loess Plateau region, China: Influence of biocrust patches and plant canopies. J. Hydrol. Eng. $18,387-393$.

Zohuriaan-Mehr, M.J., Kabiri, K., 2008. Superabsorbent polymer materials: A review. Iran. Polym. J. 17(6), 451-477. 


\section{Figures Captions}

Figure 1. Isolation and proliferation of bacteria processes (a) and cyanobacteria (b), preparation of bacteria and cyanobacteria for inoculation (c), inoculation of bacteria and cyanobacteria into the soil plots by spraying technique (d), treated plots under rainfall simulation (e), and a treated plot after completion of experiment (f)

Figure 2. Mean soil losses from control and treated plots inoculated by bacteria and cyanobacteria at different time spans

Figure 3. Microscopic images of inoculated cyanobacteria and the soil particles connection to adhesive cell walls of cyanobacteria at the initial times after inoculation (a), increasing the number and partial dimensions of cyanobacteria and the formation of soil micro-structures within 15 days after inoculation (b), dimensional expansion of the cyanobacteria and connection of soil aggregate through filaments network of cyanobacteria after 30 days of inoculation (c) and, further expansion of filaments network of cyanobacteria and soil macro-structures forming after 60 days of inoculation $(d)$ 


\section{Tables Caption}

Table 1. Results of ANOVA to statistically assess the effects of inoculation of bacteria and cyanobacteria on soil loss at three time spans 
Table 1: Results of ANOVA to statistically assess the effects of inoculation of bacteria and cyanobacteria on soil loss at three time spans

\begin{tabular}{clccccc}
\hline Time spans (day) & & Sum of squares & df & Mean square & F-value & p-value \\
\hline \multirow{2}{*}{15} & Between groups & 192.21 & 3 & 64.07 & 400.77 & 0.001 \\
& Within groups & 1.2798 & 8 & 0.16 & & \\
& Total & 193.49 & 11 & & & \\
\hline \multirow{2}{*}{30} & Between groups & 179.60 & 3 & 59.86 & 1931.16 & 0.001 \\
& Within groups & 0.248 & 8 & 0.03 & & \\
& Total & 179.84 & 11 & & & \\
\hline \multirow{2}{*}{60} & Between groups & 298.33 & 3 & 99.44 & 375.57 & 0.001 \\
& Within groups & 2.12 & 8 & 0.26 & & \\
& Total & 300.45 & 11 & & & \\
\hline
\end{tabular}



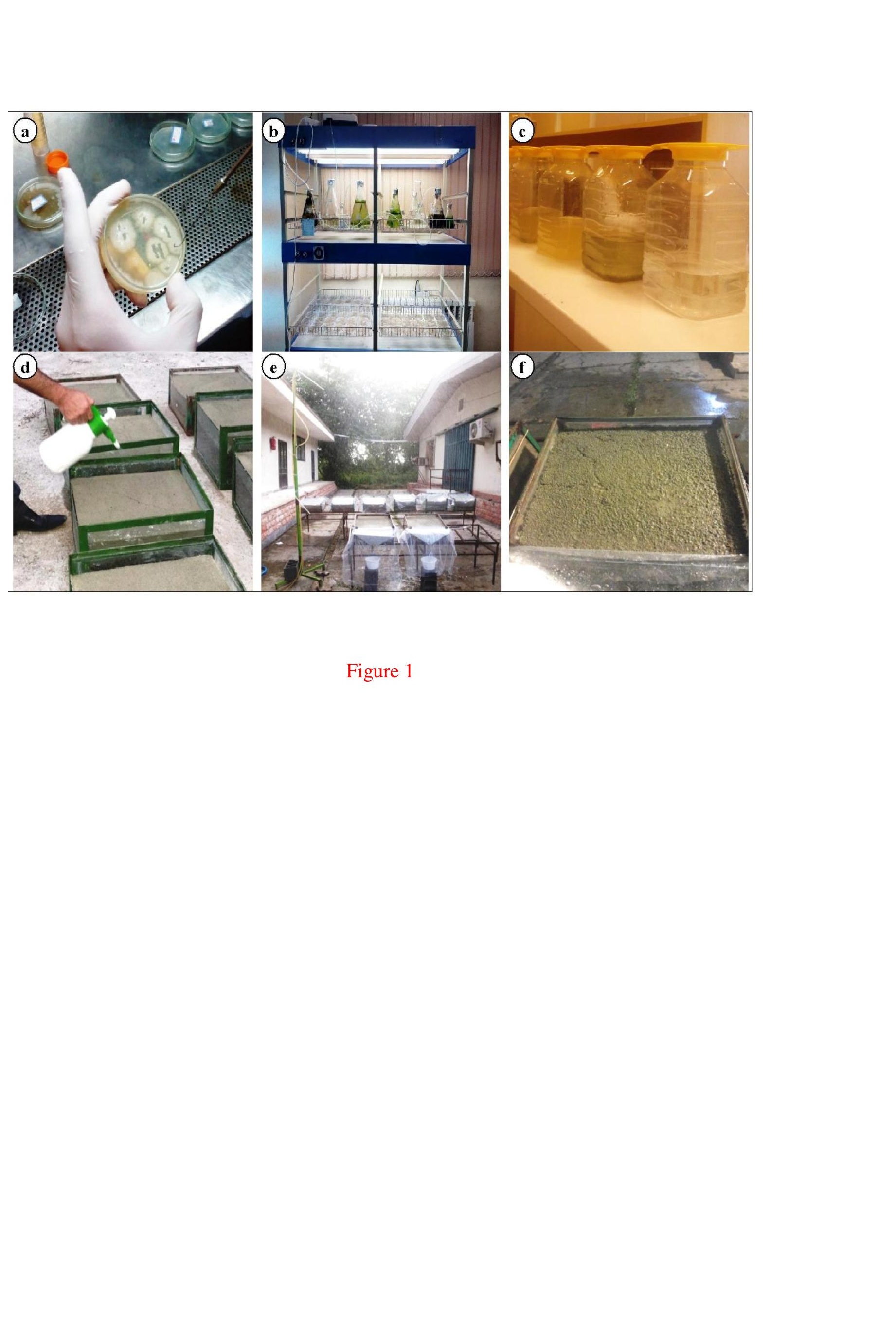

Figure 1

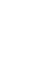

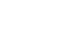

igure

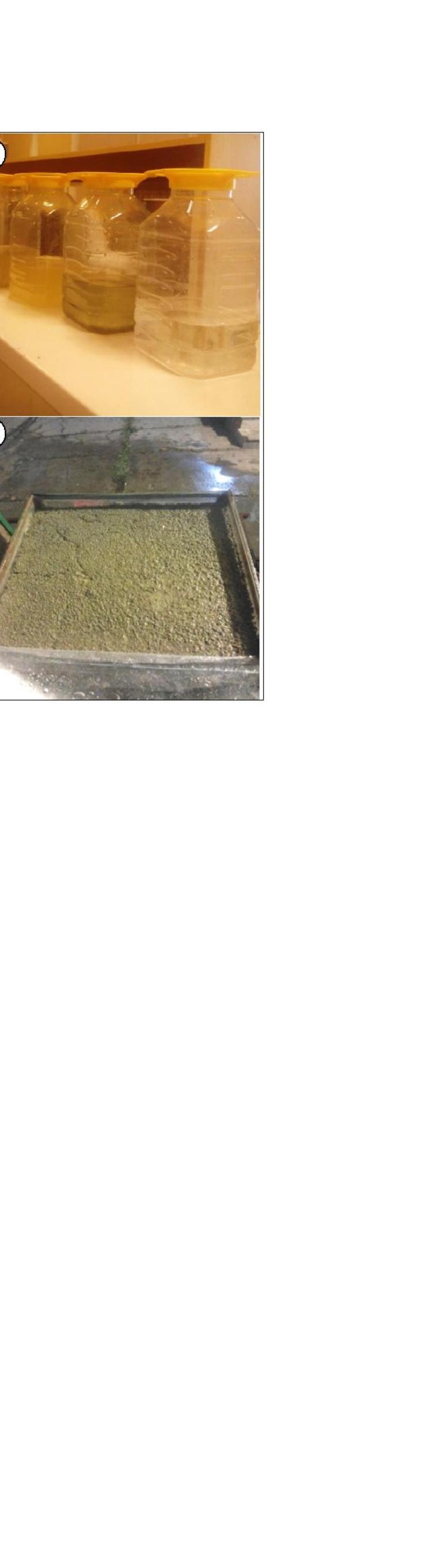




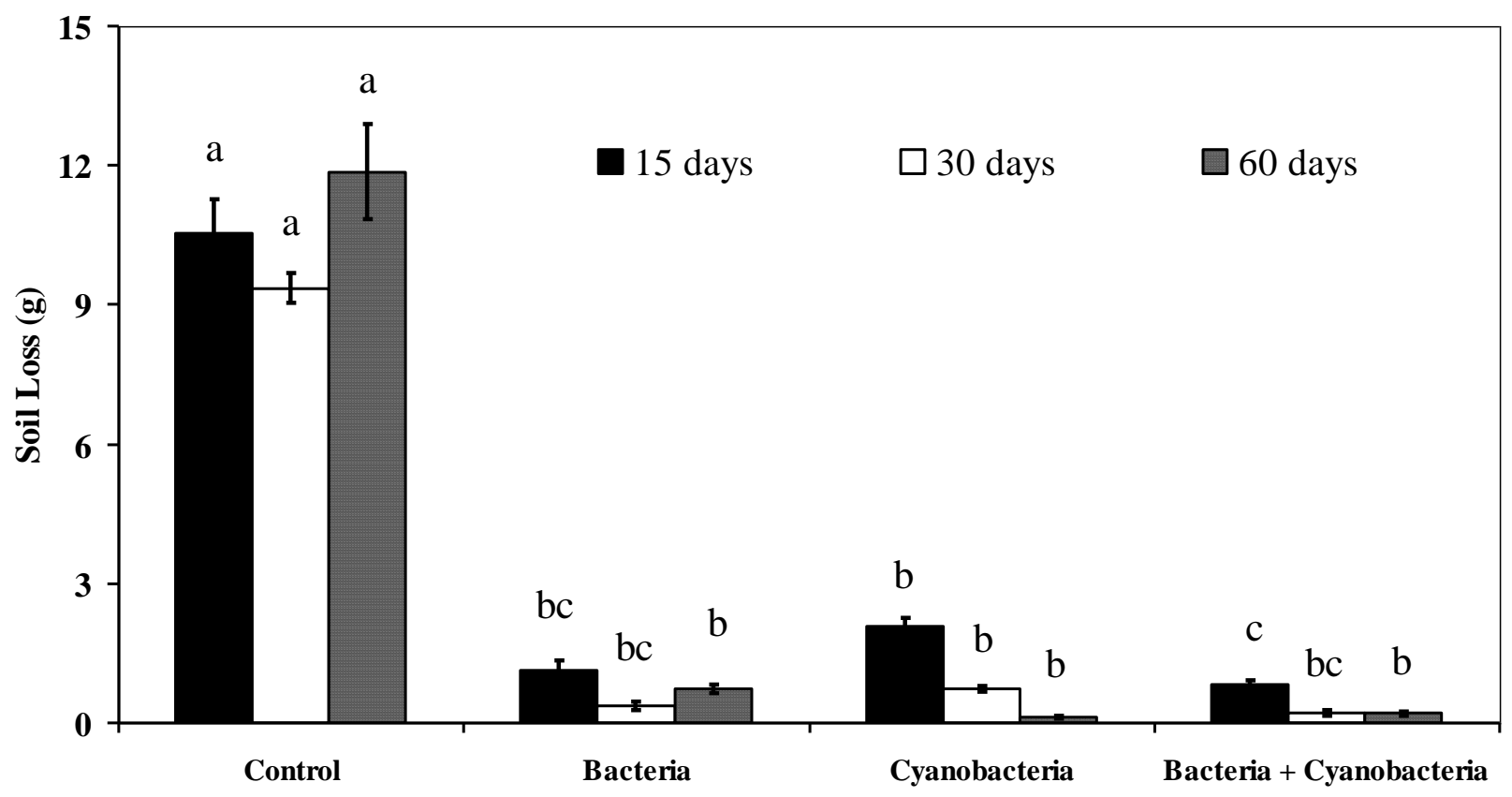

Figure 2 

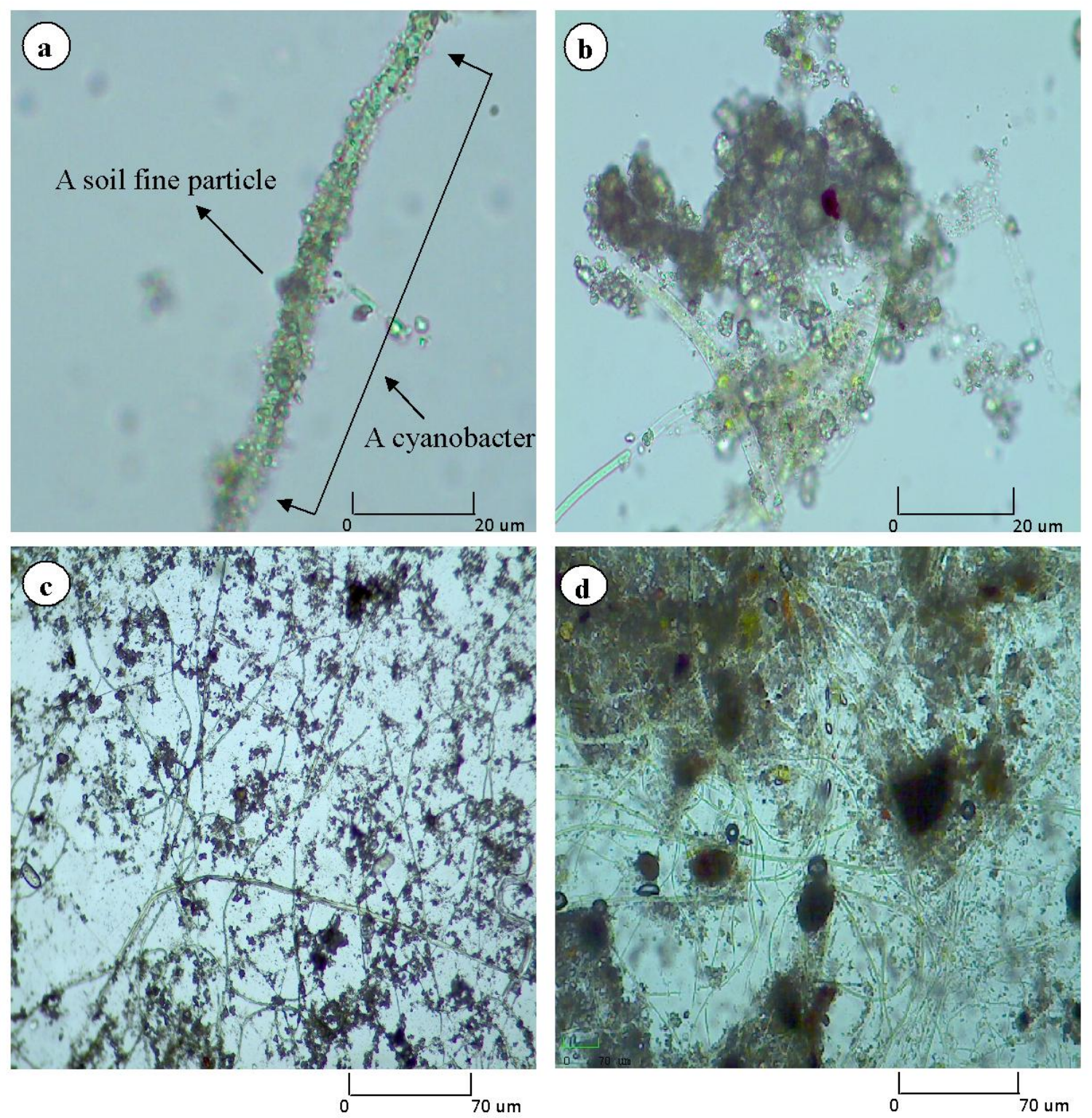

Figure 3 